\title{
DELAYED TOOTH REPLANTATION AFTER ROOT SURFACE TREATMENT WITH SODIUM HYPOCHLORITE AND SODIUM FLUORIDE: HISTOMORPHOMETRIC ANALYSIS IN RATS
}

\author{
REIMPLANTE DENTÁRIO TARDIO APÓS O TRATAMENTO DA SUPERFÍCIE RADICULAR \\ COM HIPOCLORITO DE SÓDIO E FLUORETO DE SÓDIO: \\ ANÁLISE HISTOMORFOMÉTRICA EM RATOS
}

André Dotto SOTTOVIA", Celso Koogi SONODA², Wilson Roberto POI², Sônia Regina PANZARINI², José Roberto Pereira LAURIS ${ }^{3}$

\author{
1- MSc in Maxillofacial Surgery and Traumatology, Araçatuba Dental School, UNESP, Araçatuba, SP, Brazil. \\ 2- Associate Professor, Department of Surgery and Integrated Clinics, Araçatuba Dental School, UNESP, Araçatuba, SP, Brazil. \\ 3- Assistant Professor, Department of Pediatric Dentistry, Orthodontics and Public Health, Bauru Dental School, University of São Paulo, \\ Bauru, SP, Brazil.
}

Corresponding address: André Dotto Sottovia - Rua: Valdir Filizola de Moraes 15-60, apto. 23, Bloco 5, Ed. Porto Seguro, Jd. Umuarama Cep: 161000-000 Araçatuba-SP. e-mail: sottoviafilho@uol.com.br. Fone: (014) 3223-8061.

Received: March 29, 2005 - Modification: June 1, 2005 - Accepted: December 22, 2005

\begin{abstract}
$I$

n cases of delayed tooth replantation, non-vital periodontal ligament remnants have been removed with sodium hypochlorite in an attempt to control root resorption. Nevertheless, reports of its irritating potential in contact with the alveolar connective tissue have been described. Therefore, this study evaluated the healing process on delayed replantation of rat teeth, after periodontal ligament removal by different treatment modalities. Twenty-four rats, assigned to 3 groups $(n=8)$, had their upper right incisor extracted and left on the workbench for desiccation during $60 \mathrm{~min}$. Afterwards, the teeth in group I were immersed in saline for $2 \mathrm{~min}$. In group II, root surfaces were scrubbed with gauze soaked in saline for $2 \mathrm{~min}$; and in group III, scrubbing was done with gauze soaked in 1\% sodium hypochlorite solution. Thereafter, root surfaces were etched with 37\% phosphoric acid and immersed in $2 \%$ acidulate-phosphate sodium fluoride solution, at $\mathrm{pH}$ 5.5. Root canals were filled with a calcium hydroxidebased paste and the teeth were replanted. The animals were sacrificed 60 days postoperatively and the pieces containing the replanted teeth were processed and paraffin- embedded. Semi-serial transversally sections were obtained from the middle third of the root and stained with hematoxylin and eosin for histomorphometric analysis. Data were analyzed statistically using Kruskal-Wallis and Dunn's tests. The results showed that root structure and cementum extension were more affected by resorption in group III $(\mathrm{p}<0.05)$. All groups were affected by root resorption but the treatment performed in group III was the least effective for its control. The treatment accomplished in groups I and II yielded similar results to each other.

Uniterms: Tooth replantation; Tooth avulsion; Periodontal ligament; Root resorption; Sodium hypochlorite; Sodium fluoride.
\end{abstract}

\footnotetext{
RESUMO

$E$

$\amalg$ m reimplante dentário tardio, o ligamento periodontal desvitalizado tem sido removido empregando-se o hipoclorito de sódio, buscando o controle da reabsorção radicular. Relatos de efeito irritante no tecido conjuntivo alveolar após o seu uso, têm sido descritos. Isso justificou a realização deste trabalho buscando minimizar esse inconveniente. Para isso 24 ratos, divididos em 3 grupos de 8 animais, tiveram o incisivo superior direito extraído e mantido sobre bancada para ressecamento por $60 \mathrm{~min}$. Posteriormente, os dentes do grupo I foram imersos em soro fisiológico por $2 \mathrm{~min}$. No grupo II, os dentes tiveram a superfície radicular friccionada com gaze embebida em soro fisiológico por 2 min e no grupo III a fricção foi feita empregando-se solução de hipoclorito de sódio a 1\%. Todos os dentes tiveram então a superfície radicular tratada com ácido fosfórico a 37\% seguido de imersão em solução de fluoreto de sódio fosfato acidulado a 2\%, pH 5,5. Os canais foram obturados com pasta de hidróxido de cálcio e os dentes foram reimplantados. Os animais foram sacrificados 60 dias depois e as peças contendo os dentes foram processadas em laboratório. Cortes transversais semi-seriados do terço médio da raiz, foram obtidos e corados com hematoxilinaeosina para análise histomorfométrica. Os dados obtidos foram confrontados pela análise de variância empregando-se o teste de KruskalWallis, quando este indicou diferença estatisticamente significante, utilizou-se o teste de Dunn para as comparações individuais. Os resultados demonstraram que a estrutura radicular e a extensão de cemento foram mais afetadas pela reabsorção no grupo III ( $<<0.05)$. Todos os grupos foram comprometidos pela reabsorção radicular sendo que o tratamento realizado no grupo III foi o menos efetivo para o seu controle. O tratamento realizado nos grupos I e II proporcionou resultados semelhantes entre si.
}

Unitermos: Reimplante dentário; Avulsão dentária; Ligamento periodontal; Reabsorção radicular; Hipoclorito de sódio; Fluoreto de sódio. 


\section{INTRODUCTION}

Tooth avulsion, which is characterized by complete dislodgement of the tooth from its alveolus, accounts for 0.5 to $16 \%$ of all cases of dental trauma ${ }^{2}$. It is generally well accepted that the best procedure for treating an avulsed tooth is its replantation, which can yield, at least temporarily, the reestablishment of esthetics and function ${ }^{2}$. Immediately replanted teeth have reportedly favorable prognosis ${ }^{1,20}$. However, if the extraoral time exceeds 5 minutes, a more significant post-replantation resorption process begins ${ }^{3}$.

Unfortunately, clinical practice has shown that most avulsed teeth are replanted after an extraoral time of over 60 minutes. Extensive life-threatening traumas, damaged receptor sites and lack of knowledge about replantation procedures may possibly be the main causes for this statistics ${ }^{25}$. Therefore, in spite of being acknowledged for its therapeutic value, in practice, immediate replantation is performed only in few cases ${ }^{3}$.

In conditions of delayed replantation, most of periodontal ligament (PDL) has already degenerated and root resorption may invariably lead to partial or total loss of the replanted tooth ${ }^{20}$. In such cases, special attention has been directed to replacement resorption, because no effective way to control it is currently available ${ }^{14}$.

Several treatment protocols have been attempted to increase the survival rate of avulsed teeth as proposed by Flores, et al. ${ }^{10}$ (2001) and Trope ${ }^{30}$ (2002). According to them, some procedures have been advised to be performed before replantation in an attempt to slow down the beginning of root resorption and enhance the longevity of the replanted tooth, such as immersion of the avulsed tooth in a fluoride solution to increase its resistance to resorption ${ }^{2,10,28}$. In addition, considering that the necrotic periodontal ligament stimulates root resorption ${ }^{17,19,30}$, removal of PDL remnants has also been pointed out as an advisable approach ${ }^{10,19,30}$. Although both mechanical ${ }^{2,16}$ and chemical ${ }^{9,15,19,23,26,27}$ procedures have been employed for such purpose, it has been advocated that chemical procedures aid the preservation of the cementum layer, which is more resistant to resorption and should therefore be maintained ${ }^{19}$.

Among the chemical substances usually recommended for PDL removal, sodium hypochlorite has received special attention and some studies ${ }^{9,15,27,29}$ have focused on investigating its applicability because, in addition to its capacity of dissolving connective tissue, the bactericidal properties of sodium hypochlorite are extremely suitable for replantation purposes ${ }^{9,24}$. Nevertheless, despite the low root resorption rates ${ }^{19,26}$, an optimal healing pattern has not yet been obtained with the use of sodium hypochlorite in tooth replantation protocols, and defective connective reattachment has been reported in some studies ${ }^{9,15,29}$. This effect might result from the irritating potential of sodium hypochlorite in contact with the connective tissue ${ }^{22}$ as well as from its residual effect on the root surface ${ }^{19}$. The search for a better way to use this substance has prompted the development of some studies, in which different aspects such as volume and concentration have been evaluated ${ }^{27,29}$.
Currently, this concern still remains unsolved. Therefore, the purpose of this study was to investigate whether the removal of periodontal ligament fibers by scrubbing the root surface with gauze soaked in $1 \%$ sodium hypochlorite solution, followed by $37 \%$ phosphoric acid etching and treatment with $2 \%$ sodium fluoride at $\mathrm{pH} 5.5$ would yield a better response to the healing process on delayed replantation of rat teeth.

\section{MATERIALAND METHODS}

The research was first submitted to evaluation by the local Institutional Review Board and the designed methodology was approved.

Twenty-four male Wistar rats (Rattus norvegicus, albinus), weighing 250 to $300 \mathrm{~g}$ were used in this study. The animals were obtained from the Animal Laboratory of Araçatuba Dental School/UNESP, Brazil, and were housed under climate-controlled conditions (12 h light/12 h dark; 22 $\pm 3^{\circ} \mathrm{C}$ ) with free access to ground solid ration (Mogiana Aliments S.A., Mogi das Cruzes, SP, Brazil) and water.

Before the surgical procedures, Xylazine Hydrochloride (Anasedan; AgriBrands Ltda, Campinas, SP, Brazil) was administered i.m. (0.03 mL/100 g body weight) to attain muscular relaxation and the animals were then anesthetized with Ketamine Chlorhydrate (Dopalen; AgriBrands Ltda, Campinas, SP, Brazil) at a dose of $0.07 \mathrm{~mL} / 100 \mathrm{~g}$ body weight. The rats were immobilized and had their maxillary right incisors extracted after adequate antisepsis of the teeth and surrounding tissues with iodine-polyvinylpyrrolidone (Riodeine; Ind. Farms. Rioquímica Ltda, São José do Rio Preto, SP, Brazil).

The extracted teeth were kept dry on a workbench for 60 min. Afterwards, the dental papilla and enamel organ were sectioned with a n. 15 scalpel (Embramac Exp. e Imp., Campinas, SP, Brazil), the pulps were removed through retrograde via and the canals were instrumented with a slightly curved n. $25 \mathrm{~K}$-file (Sybron Kerr). The canals were irrigated with 1\% sodium hypochlorite (Apothicário Pharmacy, Araçatuba, SP, Brasil) and saline (Ariston Ind. Quims. e Farms. Ltda, São Paulo, SP, Brasil) and dried with absorbent paper points (Dentsply Ind. e Com. Ltda., Petrópolis, RJ, Brazil). The teeth were then randomly assigned to three groups, according to the root surface treatment protocols accomplished before replantation.

In group I, the teeth were immersed in $25 \mathrm{~mL}$ of saline (Ariston Ind. Quims. e Farms. Ltda, São Paulo, SP, Brasil) for 2 min and the root surfaces were etched with a 37\% phosphoric acid gel (Dentsply Ind. e Com. Ltda., Petrópolis, Brazil) for $20 \mathrm{~s}$ and thoroughly rinsed with saline (Ariston Ind. Quims. e Farms. Ltda, São Paulo, SP, Brasil) for 2 min. The teeth were then immersed in a $2 \%$ acidulated phosphate sodium fluoride solution, pH 5.5 (Apothicário Pharmacy, Araçatuba, SP, Brazil) for $20 \mathrm{~min}$.

In group II, the root surfaces were scrubbed with gauze soaked in $25 \mathrm{~mL}$ of saline for $2 \mathrm{~min}$, acid-etched for $20 \mathrm{~s}$, rinsed with abundant saline for $2 \mathrm{~min}$ and immersed in $2 \%$ 
acidulated phosphate sodium fluoride, $\mathrm{pH} 5.5$ for $20 \mathrm{~min}$.

In group III, the root surfaces were scrubbed with a gauze soaked in $25 \mathrm{~mL}$ of $1 \%$ sodium hypochlorite solution (Apothicário Pharmacy, Araçatuba, SP, Brazil) for 2 min, acidetched for $20 \mathrm{~s}$ and the teeth were rinsed with abundant saline for 2 min and immersed in $2 \%$ acidulated phosphate sodium fluoride, $\mathrm{pH} 5.5$ for $20 \mathrm{~min}$.

It is worthy to note that effectiveness of PDL removal by 2-minute scrubbing of root surfaces with gauze soaked in $25 \mathrm{~mL}$ of $1 \%$ sodium hypochlorite was established in a pilot study.

Thereafter, the root canals of all teeth were dried with absorbent paper points (Tanariman Industrial Ltda, Manacapuru, AM, Brazil) and filled with calcium hydroxide (Calcium Hydroxid Für Analyse, Criedel, de Rainag Seelge, Hannover, Germany) and propylene glycol paste through retrograde via, using a lentulo drill (25 mm; Sybron/Kerr, Glendora, CA, USA) at low speed. The alveolar wounds were irrigated with saline and the teeth were replanted. No type of retention was made.

After replantation, the animals in all groups received 20,000 IU of penicillin G benzathine (Fort Dodge ${ }^{\circledR}$ Animal Health Ltda, Campinas, SP, Brazil), i.m., in a single dose. The animals were sacrificed by anesthetic overdose at 60 days after surgery. In each rat, the right maxilla was separated from the left by a median sagittal incision using a n. 15 scalpel. Another incision was made tangentially to the distal surface of the third molar in the right maxilla to obtain the block containing the replanted tooth.

The specimens were immersed in $10 \%$ formalin for $24 \mathrm{~h}$ for fixation and decalcified in 4.13\% EDTA solution, pH 7.0. After decalcification, the pieces were processed and embedded in paraffin. Semi-serial 6 - $\mu$ m-thick sections were cut transversally to the root surface and only those from the middle third were considered for analysis. In each specimen, the sections were cut at every $1 \mathrm{~mm}$ of root structure, providing 4 sections per tooth and 32 sections for each group. The sections were stained with hematoxylin and eosin for histological and histomorphometric analyses.

\section{Histological Analysis}

The samples were examined by optical microscopy (Carl Zeiss - Axiolab). The features of the periodontal ligament, alveolar bone, cementum and dentin, as well as the occurrence of inflammatory resorption, ankylosis and replacement resorption were evaluated. The presence or absence of periodontal ligament on the root surface, disposition of PDL fibers, reattachment of PDL fibers to root surface and existence of inflammatory infiltrate were also analyzed. The presence of bone tissue filling the PDL space and arranged juxtaposed to the cement surface was classified as dentoalveolar ankylosis. Inflammatory root resorption was characterized by the existence of connective tissue with an inflammatory infiltrate adjacent to the resorption area. Replacement resorption was defined when the resorbed root portion was filled with alveolar bone tissue.

\section{Histomorphometric Analysis}

The histomorphometric analysis was performed on the ImageLab 98 software (Diracom Bio Informatics Ltda, Vargem Grande do Sul, SP, Brazil). The images were captured with a digital camera (JVC TK-1270 Color Video Camera, São Paulo, SP, Brazil) linked to a Carl Zeiss (Axiolab) microscope connected to a computer using Vid Cap software. For measurement of the root area affected by resorption and the cementum resorption perimeter, the cross-sectional images of the root were divided into four quadrants using Paint (Microsoft) software. A final measurement was obtained by the sum of the results of the individual quadrants. The images were first recorded as figures (Tif 24) for further reading on the ImageLab 98 software (Diracom Bio Informatics Ltda, Vargem Grande do Sul, SP, Brazil). To determine the extension of intact cementum in each section, the total perimeter of root surface was calculated and the cementum resorption perimeter was subtracted from this value. These measurements were obtained using an outlining tool of ImageLab 98 software, which allowed delineation of the root contour and provided the corresponding values. To evaluate the extension to which the root was affected by the resorption process, the total root area (comprising dentin and cementum) was measured using the same outlining tool. Next, only the areas of resorption were delineated and the sum of these measurements provided the total area of root resorption. The difference between both areas (resorbed and non-resorbed) gave the percentage of root involvement of each analyzed tooth. During the measurements, the resorbed areas were classified as being caused by either inflammatory or replacement resorption, in such a way that the proportion of root involvement was obtained separately for each type of resorption.

The obtained data were entered in the Excel software (Microsoft - Office) for statistical analysis, taking into account the following aspects: areas of inflammatory resorption, areas of replacement resorption, total area of dentin resorption and extension of cementum resorption.

\section{Statistical Analysis}

Because the quantified histomorphometric parameters had great variability, data were analyzed using nonparametric statistical tests. The Kruskal-Wallis test was used to compare the data by analysis of variance and, when statistically significant differences were detected, the Dunn's method was used for individual comparisons. The significance level was established at $5 \%(\mathrm{p}<0.05)$.

\section{RESULTS}

The animals in this study bore adequately the experimental procedures and thus there were no alterations interfering with the results. Two teeth from group I were lost because of difficulties during extraction and therefore the final sample size was 22 specimens.

All groups were affected by root resorption with 
predominance of replacement resorption (Figure 1). In some areas, periodontal ligament remnants were observed surrounded by mineralized tissue without inflammatory infiltrate (Figure 2). In group III, a fibrous connective tissue with fibers oriented parallel to root surface could be seen, however without reattachment areas (Figure 3).

Extensive areas of ankylosis could be observed and were predominantly found in the specimens of groups I and II (Figures 4 and 5). No statistically significant differences $(p<0.05)$ were detected between the levels of inflammatory and replacement resorption among the three groups. Considering the thorough resorption of root structure, group III was the most affected (Table 1), showing deeper and wider resorption areas (Figure 6). This group also presented greater involvement of the cementum layer by root resorption (Figure 7). Comparison of the groups among each other showed that a statistically significant difference $(p<0.05)$ was detected only between groups II and III (Table 2).

\section{DISCUSSION}

The avulsed teeth were left dry for 60 minutes to simulate a condition of delayed tooth replantation. In such situation, periodontal ligament cells had already degenerated and the root of the replanted tooth becomes susceptible to both resorption and ankylosis processes ${ }^{12}$. Such results have been demonstrated in human ${ }^{3}$, monkey ${ }^{1}, \operatorname{dog}^{20}$ and rat

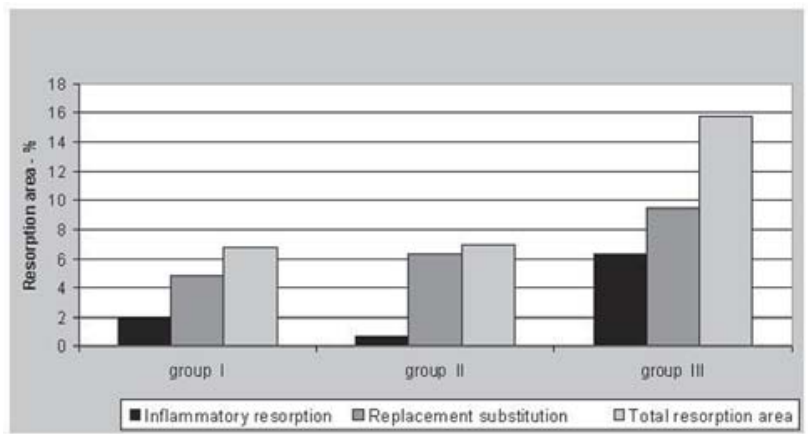

FIGURE 1- Extension of root involvement by resorption

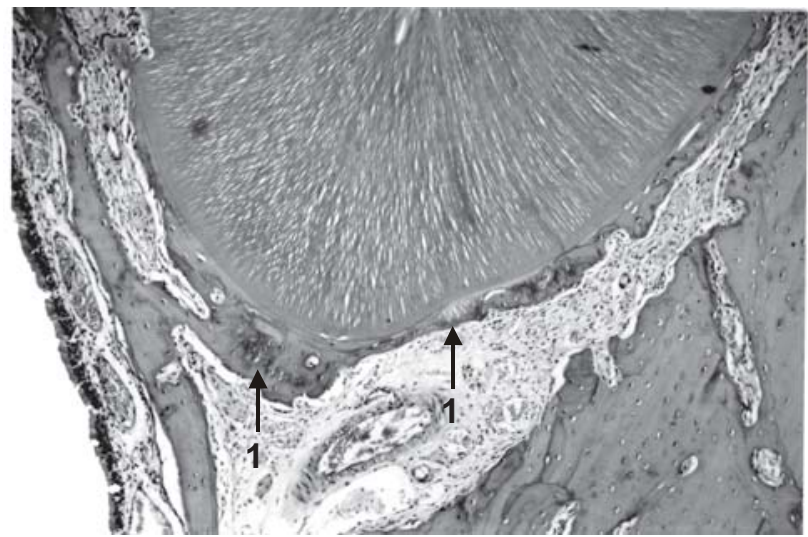

FIGURE 2- Group II. Healthy cementum covered by periodontal ligament remnants (1). Hematoxylin-eosin (original magnification X63) models ${ }^{17}$.

In this study, no statistically significant difference was observed among groups regarding the level of inflammatory resorption, which remained within the limits reported by other authors ${ }^{16}$. These results indicate that the procedures

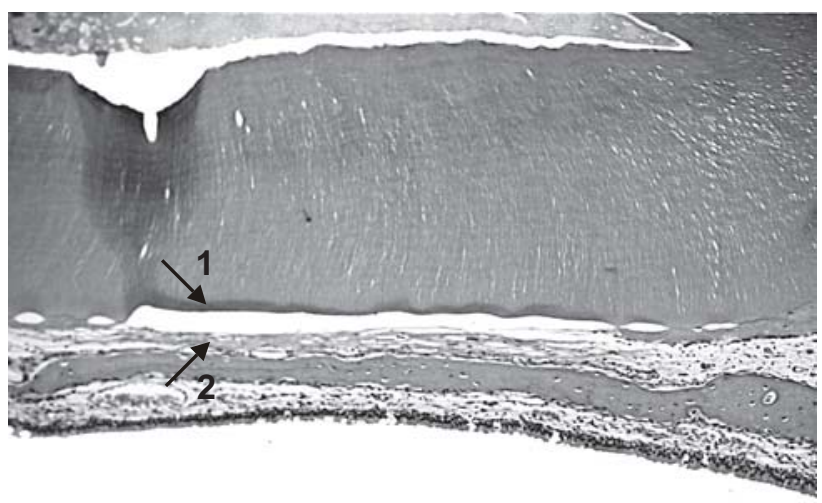

FIGURE 3- Group III. Healthy cementum covering great part of root surface (1). Fibrous connective tissue with fibers oriented parallel to root surface (2). No new attachment is observed in the cementum layer. Hematoxylin-eosin (original magnification $\mathrm{X} 160$ )

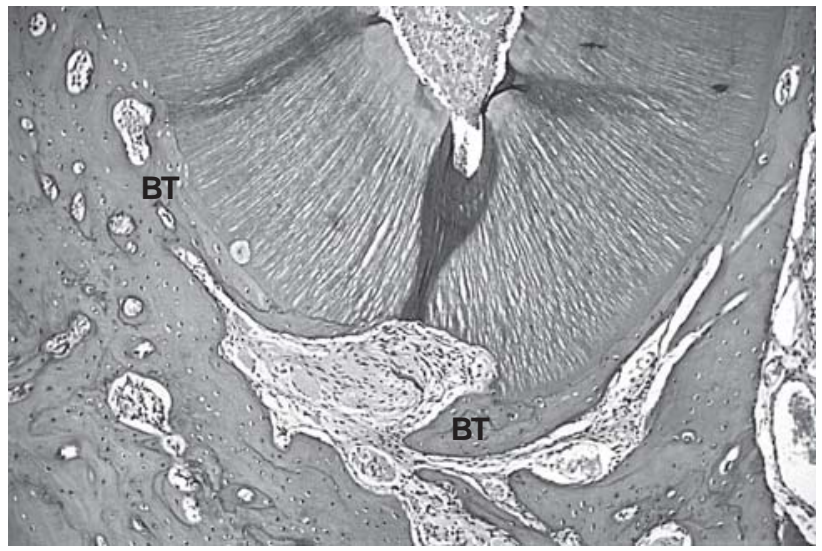

FIGURE 4- Group I. Bone tissue (BT) covering almost completely the lingual root surface. Hematoxylin-eosin (original magnification X63)

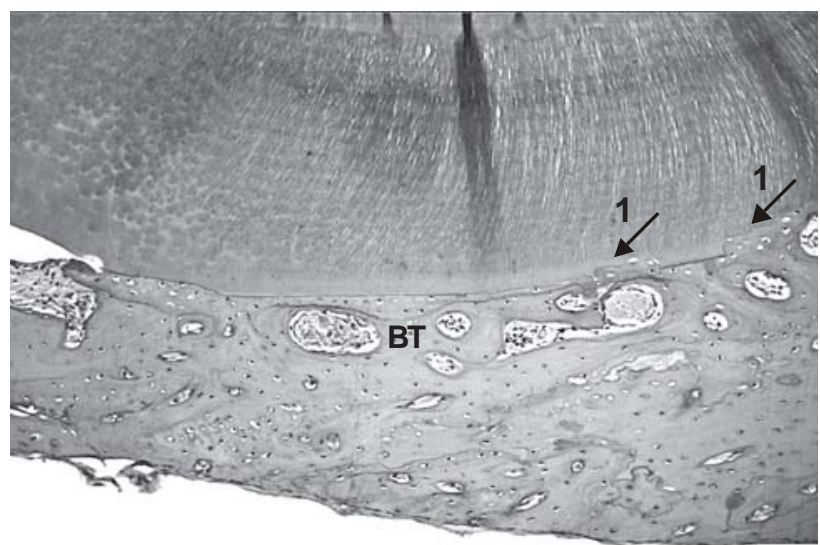

FIGURE 5- Group II. Bone tissue (BT) adjacent to an extensive area of healthy cementum. Notice the small areas of paralyzed surface resorption with bone tissue repair (1). Hematoxylin-eosin (original magnification X160) 
adopted for controlling inflammatory resorption, i.e., biomechanical preparation of root canals, filling with a calcium hydroxide-based paste ${ }^{8,18}$ and administration of systemic antibiotic therapy ${ }^{13}$ were rendered effective.

Nevertheless, the presence of necrotic periodontal ligament remnants could also contribute to the inflammatory process by the release of several enzymes and inflammation mediators along the course of the healing process ${ }^{12}$. Therefore, an interesting finding of this study was that even not using the most effective procedures for PDL removal in groups I and II, there was no increase in inflammatory resorption rates.

Acid etching of root surface has been advocated for

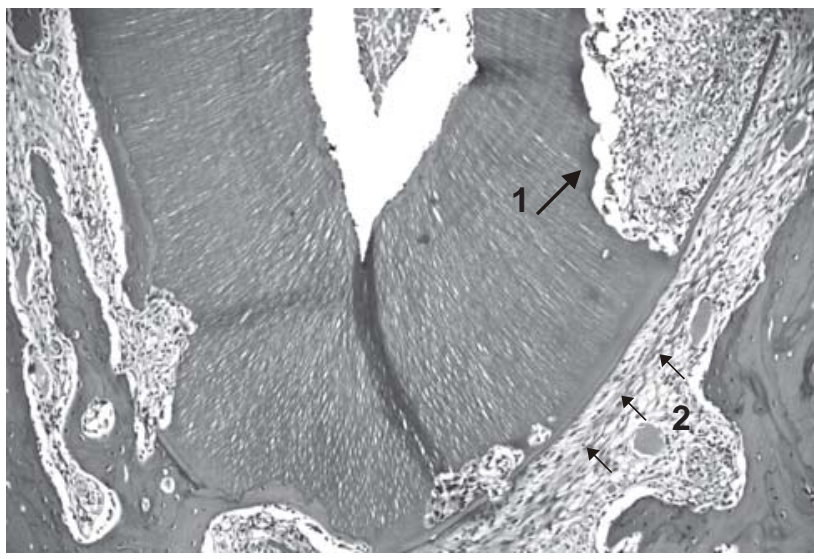

FIGURE 6- Group III. Extensive root resorption areas (1). Periodontal ligament covering the healthy root cementum layer, with PDL fibers oriented parallel to the cementum surface (2). Hematoxylin-eosin (original magnification X63)

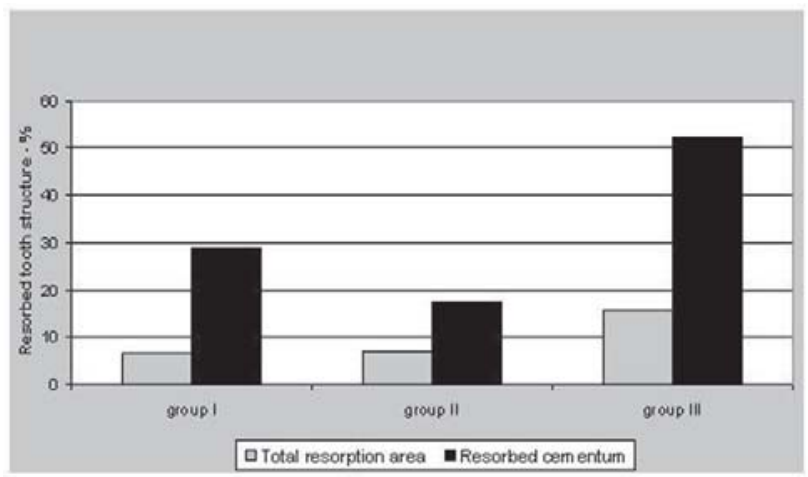

FIGURE 7- Total root resorption area and extension of cementum resorption in the different treatment groups

\begin{tabular}{cccc}
\multicolumn{4}{l}{ TABLE 1. Dunn's test for individua comparisons of tota root resorption area } \\
\hline GROUPS & AVERAGE & MIN & MAX \\
\hline GI & $6.77^{\mathbf{2}}$ & 1.02 & 10.50 \\
G II & $7.01^{\mathrm{a}}$ & 0 & 27.51 \\
G III & $15.80^{\circ}$ & 6.66 & 26.65 \\
\hline
\end{tabular}

Groups with the same letter have no statistically signific ant difference. $p<0.05$.

\begin{tabular}{cccc}
\multicolumn{4}{c}{ TABLE 2. Dunn's test for individual comparisons of cementum resorption extension } \\
\hline GROUPS & AVERAGE & MIN & MAX \\
\hline GI & $28.89^{\text {D }}$ & 11.40 & 50.04 \\
G II & $17.57^{\mathrm{a}}$ & 0 & 46.31 \\
GIII & $52.21^{\circ}$ & 25.85 & 99.99 \\
\hline
\end{tabular}

Groups wth the same letter have no statistically significant difference. $0<005$ removal of periodontal ligament remnants ${ }^{10,30}$ and a 5-minute conditioning time has been recommended ${ }^{30}$. Therefore, it may be assumed that a 20-second application, as performed in this study, was insufficient to achieve such goal. Furthermore, it may be speculated that periodontal ligament removal was more effective in group II because a mechanical technique (scrubbing) was associated with the application of $37 \%$ phosphoric acid.

Makkes et al. ${ }^{21}$ (1978) have shown that uncontaminated devitalized tissues cause low or no inflammatory reaction. In this case, it is most likely that, apart from sodium hypochlorite ${ }^{9,24}$, the acid may also have a bactericidal effect on the periodontal ligament. Accordingly, in this study, PDL remnants could be seen in some specimens of all groups that did not present an inflammatory infiltrate.

The 37\% phosphoric acid was initially used in this study to optimize the $\mathrm{pH}$ of root surface because of the use of sodium hypochlorite, which has an alkaline $\mathrm{pH}^{9,26}$. This procedure has also been recommended to expose the collagen fibers of the cementum surface and therefore yield more appropriate conditions for new connective fiber attachment $^{9}$. Nevertheless, the findings of this study are not consistent with these assumptions, as there were very few areas of connective reattachment. The general picture of ankylosis and replacement resorption observed in all groups is in agreement with Andreasen and Kristerson ${ }^{4}$ (1981), who stated that the healing of damaged areas by connective new attachment relies on the presence of a minimum amount of periodontal ligament and cementoblasts adjacent to these areas.

Previous studies on tooth replantation ${ }^{15,19}$ have reported absence of inflammatory resorption and lower root resorption rates than those found in the present investigation. Methodological differences in methodologies, i.e., experimental animal model, follow-up period ${ }^{19}$, method of sodium hypochlorite utilization and extraoral time ${ }^{15}$ may be mentioned as possible reasons for such divergent results.

Some studies with monkeys ${ }^{9}$ and rats ${ }^{15,29}$ have reported that the roots of replanted teeth appeared surrounded by a fibrous connective tissue with non-attached fibers oriented parallel to the root surface. This tissue, described as a "fibrous capsule-like structure", was shown to compromise the reinsertion of the tooth into the alveolus to the point of being easily extracted ${ }^{9}$ or even exfoliated ${ }^{29}$. In the present study, this tissue was observed in few areas of specimens in group III, but without compromising the stability of replanted teeth.

It may be observed in Figure 7 that the extension of cementum and the root structure were more compromised in group III, which indicates that the surface treatment performed in this group did not result in greater resistance to root resorption, compared to the treatments performed in the other groups. These results seem to suggest that the use of fluoride to increase root resistance to resorption might not have been effective. On the other hand, it may be speculated that root surface condition after scrubbing with sodium hypochlorite might not have been appropriate for fluoride incorporation. According to Cruz and Rölla ${ }^{7}$ (1992), 
the incorporation of fluoride ions in solutions with $\mathrm{pH} 5.5$ is much greater than with neutral $\mathrm{pH}$. Taking into account the highly alkaline $\mathrm{pH}$ of sodium hypochlorite, one would expect a less favorable condition for fluoride incorporation onto the root surface, in spite of the previous treatment with 37\% phosphoric acid.

The literature has demonstrated the effectiveness of fluoride use in both human ${ }^{6}$ and animal ${ }^{5,28}$ experimental models. Fluoride ions adsorbed to the root surface may be easily released after replantation and inhibit the action of resorption cells, probably interfering with their enzymatic activity. In addition, there would be formation of fluoroapatite, which is more resistant to the root resorption process $^{28}$. Such evidences have led different authors to advise the use of fluoride for root surface treatment in delayed tooth replantation ${ }^{2,10,30}$.

Nevertheless, it has been reported that fluoride incorporation is more effective in the outermost layer of the root, not reaching the deeper dentin layers ${ }^{11}$. We believe that this may pose limitations to the role of fluoride in tooth replantation, because after surpassing the "resistance" of the outermost layer, root resorption would progress into the underlying dentin tissue.

The existence of several areas of replacement resorption in all specimens evaluated in this study denoted that the progress of healing process might result in complete root resorption of the replanted tooth. Despite the fact that there is still no effective method to totally control this resorption ${ }^{30}$, it must be noticed that the choice for certain types of root surface treatments may produce specimens less compromised by resorption than others, which indicates that there is a possibility of longer survival. This fact highlights the need for investigating root surface treatment options and the importance of performing tooth replantation even when the conditions are not exactly favorable.

\section{CONCLUSIONS}

According to the methodology proposed and based on the findings of this study, it may be concluded that in delayed replantation of rat teeth:

1. none of the treatment protocols is capable of completely avoiding root resorption;

2. the removal of periodontal ligament remnants by scrubbing with gauze soaked in 1\% sodium hypochlorite plus phosphoric acid etching plus immersion in $2 \%$ acidulated phosphate sodium fluoride is not effective for controlling root resorption;

3. the treatment with phosphoric acid etching and $2 \%$ acidulated phosphate sodium fluoride or removal of periodontal ligament by scrubbing with a gauze soaked in saline plus acid-etching plus immersion in $2 \%$ acidulated phosphate sodium fluoride results in similar incidence of root resorption.

\section{REFERENCES}

1- Andreasen JO. Effect of extra-alveolar period and storage media upon periodontal and pulpal healing after replantation of mature permanent incisors in monkeys. Int J Oral Surg. 1981;10(1):43-53.

2- Andreasen JO, Andreasen FM. Avulsões. In: Andreasen, JO, Andreasen FM. Texto e atlas colorido de traumatismo dental. Porto Alegre: Artmed; 2001. p.383-425

3- Andreasen JO, Borum MK, Jacobsen HL, Andreasen FM. Replantation of 400 avulsed permanent incisors 4. Factors related to periodontal ligament healing. Endod Dent Traumatol. 1995;11(2):7689.

4- Andreasen JO, Kristerson L. The effect of limited drying or removal of the periodontal ligament. Periodontal healing after replantation of mature permanent incisors in monkeys. Acta Odontol Scand. 1981;39(1):1-13.

5- Björvatn K, Massler M. Effect of fluorides on root resorption in replanted rat molars. Acta Odontol Scand. 1971;29(1):17-29.

6- Coccia CT. A clinical investigation of root resorption rates in reimplanted young permanent incisors: a five-year study. J Endod. 1980;6(1):413-20.

7- Cruz R, Rölla G. The effect of time of exposure on fluoride uptake by human enamel from acidulated fluoride solutions in vitro. Acta Odontol Scand. 1992;50(1):51-6.

8- Cvek M, Granath LE, Hollender L. Treatment of non vital permanent incisors with calcium hidroxide 3 . Variation of occurrence of ankylosis of reimplanted teeth with duration of extra-alveolar period and storage environment. Odontol Revy. 1974;25(1):43-56.

9- Ehnevid H, Lindskog S, Jansson L, Blomlölf L. Tissue formation on cementum surfaces in vivo. Swed Dent J. 1993;17(1-2):1-8.

10- Flores MT, Andreasen JO, Bakland LK, Feiglin B, Oikarinem K, Gutmann SL, et al. Guidelines for the evaluation and management of traumatic dental injuries. Dent Traumatol. 2001;17(5):193-8.

11- Gedalia I, Shulman LB, Albert M, Goldhaber P, Sciaky I. The fluoride content in root layers of fluoride immersed teeth. Pharmacol Ther Dent. 1970;1:151-6

12-Hammarström L, Blomlöf L, Lindskog S. Dynamics of dentoalveolar ankylosis and associated root resorption. Endod Dent Traumatol. 1989;5(4):163-75.

13- Hammarström L, Blomlöf L, Feiglin B, Andersson L, Lindskog S. Replantation of teeth and antibiotic treatment. Endod Dent Traumatol. 1986;2(2):51-7.

14- Hammarström L, Pierce A, Blomlöf L, Feiglin B, Lindskog S. Tooth avulsion and replantation: a review. Endod Dent Traumatol. 1986;2(1):1-8.

15- Kanno CM, Saad Neto M, Sundfeld MLMM, Velasco-Bohórques MP. Reimplante mediato de dentes tratados ou não com solução de hipoclorito de sódio a 1\%: estudo histomorfométrico em ratos. Pesqui Odontol Bras. 2000;14(2):151-7.

16- Lam K, Sae-Lim V. The effect of Emdogain gel on periodontal healing in replanted monkeys' teeth. Oral Surg Oral Med Oral Pathol Oral Radiol Endod. 2004;97(1):100-7.

17- Leite MC, Okamoto T. The influence of extra-oral time upon healing after tooth replantation: a histological study in rat incisors. J Nihon Univ Sch Dent. 1984;26(4):316-30. 
18- Lengheden A, Blomlöf L, Lindskog S. Effect of immediate calcium hydroxide treatment and permanent root-filling on periodontal healing in contaminated replanted teeth. Scand J Dent Res. 1991;99(2):139-46

19- Lindskog S, Pierce AM, Blomlöf L, Hammarström L. The role of the necrotic periodontal membrane in cementum resorption and ankylosis. Endod Dent Traumatol. 1985;1(3):96-101.

20- Löe H, Waerhaug J. Experimental replantation of teeth in dogs and monkeys. Arch Oral Biol. 1961;3:176-84.

21- Makkes PC, Van Velzen SKT, Van Den Hooff A. The response of the living organism to dead and fixed dead enclosed homologous tissue. Oral Surg Oral Med Oral Pathol. 1978;46(2):296-306.

22- Moorer WR, Wesselink PR. Factors promoting the tissue dissolving capability of sodium hypoclorite. Int Endod J. 1982;15(4):187-96.

23- Nevins AJ, Laporta RF, Borden BG, Lonrenzo P. Replantation of enzimatically treated teeth in monkeys. Part I. Oral Surg Oral Med Oral Pathol. 1980;50(3):277-81

24- Ohara P, Torabinejad M, Kettering JD. Antibacterial effect of various endodontic irrigants on selected anaerobic bacteria. Endod Dent Traumatol. 1993;9(3):95-100.

25- Panzarini SR, Saad Neto M, Sonoda CK. Poi WR, Carvalho ACP. Avulsões dentárias em pacientes jovens e adultos na região de Araçatuba. Rev Assoc Paul Cir Dent. 2003;57(1):27-31.

26- Percinoto C, Russo MC, Lima JEO, Andrioni JN, Benfatti SV, Bertoz FA. Processo de reparo em dentes reimplantados após a remoção química das fibras periodontais radiculares. Rev Odontol UNESP. 1988;17(1/2):73-81.

27- Poi WR, Panzarini SR, Sonoda CK, Fernandes U, MORI GG. Influência do volume de hipoclorito de sódio a $1 \%$ na remoção do ligamento periodontal necrosado. Rev Assoc Paul Cir Dent. 2001;55(4):286-9.

28- Shulman LB, Gedalia I, Feingold RM. Fluoride concentration in root surfaces and alveolar bone of fluoride-immersed monkey incisors three weeks after replantation. J Dent Res. 1973;52(6):1314-6.

29- Sonoda CK, Poi WR, Okamoto T, Toyota E, Takeda RH. Reimplante imediato de dentes após o tratamento da raiz com solução de hipoclorito de sódio a 1\%, 2,5\%, 5\% e 10\%. Rev Bras Odontol. 2000;57(5):293-6.

30- Trope M. Clinical management of the avulsed tooth: present strategies and future directions. Dent Traumatol. 2002;18(1):1-11. 